\title{
Training Needs Assessment of Tomato Growers in West Jaintia Hills District of Meghalaya, India
}

\author{
Ebiangmitre Pale*, Daya Ram, M. Deepa Devi and N. Okendro Singh \\ Department of Extension Education, College of Agriculture, Central Agricultural University, \\ Imphal-795004, Manipur (India) \\ *Corresponding author
}

\begin{tabular}{|c|c|}
\hline & A B S T R A C T \\
\hline & \multirow{6}{*}{$\begin{array}{l}\text { Tomato (Solanum lycopersicum) is an important commercial vegetable of tropical and } \\
\text { subtropical regions of India. Tomato growers need proper and regular training with regarc } \\
\text { to cultivating of tomato as it needs close attention in detail and continuous care from } \\
\text { sowing time to harvesting. Training has become a critical input in view of the growing } \\
\text { sophistication in agricultural technology as well as its cost intensive nature. Study revealec } \\
\text { that variables like education, innovation proneness, economic motivation and extension } \\
\text { contact were significant at } 0.01 \text { level of probability with ' } r \text { ' value } 0.245^{* *}, 0.374^{* *} \text {, } \\
0.753^{* *} \text { and } 0.406^{* *} \text { respectively, whereas family type and mass media exposure were } \\
\text { found significant at } 0.05 \text { level of probability with ' } r \text { ' value } 0.228^{*} \text { and } 0.188^{*} \text { respectively } \\
\text { These were the most important factors that have influence on the training needs } \\
\left.\text { assessment. Further, family type with ' } t \text { ' value ( } 3.577^{* *}\right) \text {, innovation proneness }\left(2.994^{* *} \text { ) }\right. \\
\text { and economic motivation }\left(10.831^{* *}\right) \text { were found significant at } 0.01 \text { level of probability } \\
\text { whereas extension contact }\left(2.559^{*}\right) \text { was found significant at } 0.05 \text { level of probability may } \\
\text { be termed as good predictors that can be effectively use as a tool for the assessment of } \\
\text { training needs of tomato growers in Meghalaya. }\end{array}$} \\
\hline & \\
\hline $\begin{array}{l}\text { Tomato, Variables, } \\
\text { Training needs } \\
\text { assessment, } \\
\text { Meghalaya }\end{array}$ & \\
\hline Article Info & \\
\hline $\begin{array}{l}\text { Accepted: } \\
\text { 17 April } 2019 \\
\text { Available Online: } \\
10 \text { May } 2019\end{array}$ & \\
\hline & \\
\hline
\end{tabular}

\section{Introduction}

Tomato is one of the most important "Protective foods" because of its special nutritive value and widespread production. Meghalaya has a total land area of around 22,430 square kilometers. Tomato covers an area of 1965 hectares with a production of $30224 \mathrm{MT}$ and productivity $15492 \mathrm{kgs} / \mathrm{ha}$ in the state. (Source: Directorate of Economics and Statistics, Government of Meghalaya, 2012-13).
In terms of the amount of vitamins and minerals content, tomato contributes immensely to the diet of the people and is known to be the second most important vegetable crop in the world. Tomato growers need proper and regular training with regard to cultivating of tomato as it needs close attention in detail and continuous care from sowing time to harvesting. A need-based training to bring desirable changes in knowledge, skills, and attitude of the farmers is necessary. Training is a must to induce motivation; create confidence and inculcate 
efficiency in an individual. Tomato production requires high level of inputs, labour, maintenance and supervision. Transferring of new technology is the main focus of training programmes and also they need to be result oriented. For advancement of human performance, training programmes need to provide systematic improvement of knowledge and skills.

The widespread availability of fertilizers, pesticides and improved high yielding varieties has help tomato production keep pace with the production growth. With new diseases and insect plagues, the breeders managed to come up with new resistant varieties and protection with the help of chemicals. Therefore, for realizing more productivity and production of crop, the tomato growers need to be properly trained in the latest improved cultivation practices and management.

\section{Materials and Methods}

The present study was conducted in the year 2018-19. Ex post facto research design was adopted for the study. West Jaintia Hills District was selected purposively for the study. Thadlaskein Block was selected purposively out of the three blocks in the particular district. Six villages were randomly selected on the basis of larger tomato grower's coverage area. A total of 120 tomato growers were selected through proportionate allocation random sampling method in which twenty numbers of respondents were selected from each village.

The primary data were collected with the help of the structured schedule through personnel interview method. The data analysis was done by using statistical methods like frequency, percentage, standard deviation, Pearson product moment coefficient of correlation and multiple regression analysis.

\section{Results and Discussion}

It was observed from Table 1 that the mean scores of the most important training areas was found in "Application of manures and fertilizers" with $2.47 \mathrm{MS}$ and was ranked first place, followed by "Plant protection measures" with 2.36 MS and ranked second place. The mean score of other training areas like "Sowing and high yielding varieties, Irrigation management, Harvesting/Storage, Preparation of nursery bed, Preparation of soil, Transplanting, Seed rate/ Seed treatment, Weed control and Processing," were 2.33, $2.30,2.29,2.20,2.14,2.13,2.11,2.07$ and 2.03 respectively, and were ranked 3rd, 4th, 5th, 6th, 7th, 8th, 9th, 10th and 11th places, respectively.

It was found from Table 2 that 70.83 per cent of the tomato growers belonged to medium training needs assessment category followed by 17.50per cent belonged to low training needs assessment category and 11.67per cent belonged to high training needs assessment category.

From Table 3 it was observed that all the significant variables were positive. Education was found significant at 0.01 level of probability with ' $r$ ' value 0.245 . This denote that higher the level of education, higher the training need areas of the tomato growers. Similar finding comply with the study by Srivastava (2012). Family type was found significant at 0.05 level of probability with ' $r$ ' value 0.228 . This denote that higher the level of family type, higher the training need areas of the tomato growers. Similar finding comply with the study by Parida (2010). Innovation proneness was found significant at 0.01 level of probability with ' $r$ ' value 0.374 . This indicates that higher the innovation proneness higher the training need of tomato cultivation. Similar finding comply with the study by Devi and Verma (2009). Economic 
motivation was found significant at 0.01 level of probability with ' $r$ ' value 0.753 . This indicates that higher the economic motivation higher the training need areas of tomato growers. Similar finding comply with the study by Devi and Verma (2009). Extension contact was found significant at 0.01 level of probability with ' $r$ ' value 0.406 . This denote that higher the level of extension contact, higher the training need areas of the tomato growers. Similar finding comply with the study by Verma et al., (2013). Mass media exposure was found significant at 0.05 level of probability with ' $r$ ' value 0.188 . This denote that lower the exposure to mass media lower the level of training need areas of the tomato growers. Similar finding comply with the study by Shadiadeh (1982).
From above analysis (Table 4) it was found that estimated co-efficient for family type was positive (1.264) and had t-value (3.557). The estimated co-efficient for innovation proneness was positive (0.427) and had tvalue (2.994). The estimated co-efficient for economic motivation was positive (4.835) and had t-value (10.831). The estimated coefficient for extension contact was positive (0.172) and had t-value (2.559). Therefore, these four variables whose regression coefficient value (b) were significant may be termed as good predictors that can be effectively use as a tool for the assessment of training needs of tomato growers in the future.

Table.1 Training needs assessment areas of tomato growers $n=120$

\begin{tabular}{|c|c|c|c|c|c|c|c|c|c|}
\hline \multirow[t]{2}{*}{ Sl. No. } & \multirow[t]{2}{*}{ Area of Training } & \multicolumn{2}{|c|}{$\begin{array}{c}\text { Most } \\
\text { important }\end{array}$} & \multicolumn{2}{|c|}{ Important } & \multicolumn{2}{|c|}{ Least important } & \multirow[t]{2}{*}{ Mean score } & \multirow[t]{2}{*}{ Rank } \\
\hline & & Freq. & $\%$ & Freq. & $\%$ & Freq. & $\%$ & & \\
\hline 1. & $\begin{array}{l}\text { Preparation of nursery } \\
\text { bed }\end{array}$ & 90 & 75.00 & 9 & 7.50 & 21 & 17.50 & 2.20 & VI \\
\hline 2. & Preparation of soil & 99 & 82.50 & 8 & 6.67 & 13 & 10.83 & 2.14 & VII \\
\hline 3. & $\begin{array}{l}\text { Seed rate/ Seed } \\
\text { treatment }\end{array}$ & 96 & 80.00 & 16 & 13.33 & 8 & 6.67 & 2.11 & IX \\
\hline 4. & $\begin{array}{l}\text { Sowing and high } \\
\text { yielding varieties }\end{array}$ & 75 & 62.50 & 20 & 16.67 & 25 & 20.83 & 2.33 & III \\
\hline 5. & Transplanting & 106 & 88.33 & 1 & 0.83 & 13 & 10.83 & 2.13 & VIII \\
\hline 6. & $\begin{array}{l}\text { Application of manures } \\
\text { and fertilizers }\end{array}$ & 44 & 36.6 & 60 & 50.00 & 16 & 13.33 & 2.46 & I \\
\hline 7. & Irrigation management & 35 & 29.17 & 75 & 62.50 & 10 & 8.33 & 2.30 & IV \\
\hline 8. & Weed control & 101 & 84.17 & 10 & 8.33 & 9 & 7.50 & 2.07 & $\mathrm{X}$ \\
\hline \multirow[t]{4}{*}{9.} & \multicolumn{9}{|c|}{ Plant protection measures } \\
\hline & a) Insect pest control & 83 & 69.17 & 2 & 1.67 & 35 & 29.17 & \multirow[t]{3}{*}{2.36} & \multirow[t]{3}{*}{ II } \\
\hline & b) disease control & 90 & 75.00 & 14 & 711.6 & 16 & 13.33 & & \\
\hline & $\begin{array}{l}\text { c)physiological } \\
\text { disorder's control }\end{array}$ & 46 & 38.33 & 11 & 9.17 & 63 & 52.50 & & \\
\hline 10. & $\begin{array}{l}\text { Harvesting/ } \\
\text { Storage }\end{array}$ & 75 & 62.50 & 37 & 30.83 & 8 & 6.67 & 2.29 & V \\
\hline 11. & Processing & 114 & 95.00 & 3 & 2.50 & 3 & 2.50 & 2.03 & XI \\
\hline
\end{tabular}


Table.2 Distribution of tomato growers in accordance to their overall training need areas

\begin{tabular}{|c|c|c|c|c|}
\hline Sl. No & Category & Frequency & Percentage & Mean \\
\hline $\mathbf{1}$ & Low & 21 & $17.50 \%$ & \multirow{2}{*}{107.3} \\
\hline $\mathbf{2}$ & Medium & 85 & $70.83 \%$ & \\
\cline { 1 - 4 } $\mathbf{3}$ & High & 14 & $11.67 \%$ & \\
\hline & TOTAL & 120 & $100.00 \%$ & \\
\hline
\end{tabular}

Table.3 Correlation coefficients of independent variables with their training need areas

\begin{tabular}{|c|c|c|}
\hline Sl. No. & Variable & $\begin{array}{c}\text { Correlation coefficient } \\
\text { ' } r \text { ' }\end{array}$ \\
\hline 1. & Age & $0.042(\mathrm{NS})$ \\
\hline 2. & Education & $0.245^{* *}$ \\
\hline 3. & Family type & $0.228^{*}$ \\
\hline 4. & Land holding & $0.079(\mathrm{NS})$ \\
\hline 5. & Family income & $0.048(\mathrm{NS})$ \\
\hline 6. & Social Participation & 0.003 (NS) \\
\hline 7. & Risk orientation & $0.106(\mathrm{NS})$ \\
\hline 8. & Innovation proneness & $0.374^{* *}$ \\
\hline 9. & Economic motivation & $0.753^{* *}$ \\
\hline 10. & Extension contact & $0.406^{* *}$ \\
\hline 11. & Mass media exposure & $0.188^{*}$ \\
\hline
\end{tabular}

** Significant at the 0.01 level of probability (2-tailed).

* Significant at the 0.05 level of probability (2-tailed).

NS-Non Significant

Table.4 Regression coefficients for the training need areas of tomato growers

\begin{tabular}{|r|l|r|r|r|r|}
\hline Sl. No. & Independent variables & \multicolumn{1}{|c|}{ Beta } & $\begin{array}{c}\text { Regression } \\
\text { co-efficient (b) }\end{array}$ & $\begin{array}{c}\text { Standard } \\
\text { error }\end{array}$ & \multicolumn{1}{c|}{ t-value } \\
\hline $\mathbf{1 .}$ & Age & .051 & .024 & .028 & .863 \\
\hline $\mathbf{2 .}$ & Education & .066 & .171 & .164 & 1.042 \\
\hline $\mathbf{3 .}$ & Family type & .213 & 1.318 & .369 & $3.577 * *$ \\
\hline $\mathbf{4 .}$ & Land holding & -.105 & -.419 & .272 & -1.541 \\
\hline $\mathbf{5 .}$ & Family income & -.107 & -.368 & .207 & -1.777 \\
\hline $\mathbf{6 .}$ & Social Participation & .001 & .000 & .015 & .012 \\
\hline $\mathbf{7 .}$ & Risk orientation & .051 & .069 & .080 & .862 \\
\hline $\mathbf{8 .}$ & Innovation proneness & .182 & .364 & .122 & $2.994^{* *}$ \\
\hline $\mathbf{9 .}$ & Economic motivation & .644 & 4.737 & .437 & $10.831^{* *}$ \\
\hline $\mathbf{1 0 .}$ & Extension contact & .171 & .354 & .138 & $2.559^{*}$ \\
\hline $\mathbf{1 1 .}$ & Mass media exposure & .098 & .214 & .140 & 1.537 \\
\hline
\end{tabular}

** Significant at the 0.01 level of probability

* Significant at the 0.05 level of probability $\mathrm{R}^{2}=0.700 \quad \mathrm{~F}=22.896$ 
The calculated $F$ value (22.896) and value $\mathrm{R}^{2}(0.700)$ from the above Table 4 suggested that all the variables jointly contributed $70.00 \%$ towards the training need areas of tomato growers.

In conclusion, training plays a significant role in acceleration human behaviour needed for development in fields with a growing satisfaction in technology. Training has become a critical input in view of the growing sophistication in agricultural technology as well as its cost intensive nature. Transferring of new technology is the main focus of training programme and also they need to be result oriented. Study revealed that education, family type, innovation proneness, economic motivation, extension contact and mass media exposure were most important factors that have influence on the training need areas of tomato growers respectively. Further, family type, innovation proneness, economic motivation and extension contact may be termed as good predictors that can be effectively use as a tool for the assessment of training needs of tomato growers in Meghalaya.

\section{Acknowledgement}

The authors acknowledge the contributions of Ebiangmitre Pale, Daya Ram, M. Deepa Devi and N. Okendro Singh, College of Agriculture, Central Agricultural University, Imphal, Manipur (India) for their technical support and valuable contributions to the manuscript.

\section{References}

Devi, U., and Verma, S.K. (2009). Technological training need and interest of the farm women for different crop cultivation operations of Haryana State. Asian Journal of Home Science, 4(1): 50-55.

Parida, S., (2010) Utilization of information and communication technology (ICT) tools by staff and students in universities. M.Sc. Thesis, University of Agricultural Sciences, Dharwad.

Shadiadeh, A.N.H.Al. (2007). Descriptive study of the training needs for men and women farmers in semi desert areas a case study of South Jordan. World Applied Sciences Journal, 2(1): 12-21.

Srivastava, A.K., Gupta, V.K., Lal, B., Roy, S., Yadav, S.K., Gurjar, M.S., Bag, T.K., Pandey, N.K. and Singh, B.P. (2012). Assessment of the level of knowledge and training needs of potato growing tribal farmers of Meghalaya. International Journal of Agriculture, Environment \& Biotechnology, 5(4): 483-487.

Verma, H.K., Patel, B.M., Patel, J.K. and Gulkari, K.D. (2013). Training needs assessment of marigold growers. Agriculture Update, 8(1/2): 257-259.

\section{How to cite this article:}

Ebiangmitre Pale, Daya Ram, M. Deepa Devi and Okendro Singh, N. 2019. Training Needs Assessment of Tomato Growers in West Jaintia Hills District of Meghalaya. Int.J.Curr.Microbiol.App.Sci. 8(05): 2147-2151. doi: https://doi.org/10.20546/ijcmas.2019.805.252 